\title{
KEPADATAN POPULASI HAMA DAN MUSUH ALAMI PADA PERTANAMAN PADI (Oryza sativa L.) VARIETAS INPARI 10 YANG DIBUDIDAYAKAN SECARA PHT VERSUS KONVENSIONAL.
}

\author{
Inggit Sagita, F. X. Susilo, I. Gede Swibawa \& Purnomo \\ Jurusan Agroteknologi, Fakultas Pertanian Universitas Lampung \\ Jl. Prof. Soemantri Brodjonegoro, No. 1, Bandar Lampung 35145 \\ E-mail: inggitsagita38@yahoo.com
}

\begin{abstract}
ABSTRAK
Penelitian ini bertujuan untuk membandingkan kepadatan populasi hama dan musuh alami pada pertanaman padi Varietas Inpari 10 yang dibudidayakan secara PHT dan Konvensional. Lahan berukuran 50x25 $\mathrm{m}^{2}$ masing-masing ditanami padi yang dibudidayakan secara PHT dan konvensional. Pada masing- masing lahan diamati enam rumpun sampel yang diambil secara sistematis. Pengambilan data sejak 30 hst dan dilakukan seminggu sekali sampai 79 hst. Hasil penelitian menunjukan bahwa populasi hama yang didapatkan pada pertanaman padi secara PHT tidak berbeda nyata dengan konvensional (non-PHT). Populasi musuh alami yang didapatkan pada pertanaman PHT juga tidak berbeda nyata pada petak konvensional, kecuali ketika 30 hst pengamatan, populasi musuh alami pada petak PHT lebih tinggi dari pada petak konvensional (non-PHT).
\end{abstract}

Kata Kunci: Padi Varietas Inpari 10, hama, musuh alami, PHT .

\section{PENDAHULUAN}

Beras merupakan bahan makanan pokok bagi sebagian besar penduduk Indonesia. Semakin bertambahnya penduduk di Indonesia, semakin meningkat juga kebutuhan beras bagi penduduk. Hal ini yang mendorong pemerintah untuk melaksanakan program peningkatan produksi padi. Serangan hama menjadi salah satu kendala dalam peningkatan produksi padi. Untuk mengatasi permasalahan ini, petani umumnya melakukan penyemprotan insektisida. Namun, dengan penyemprotan insektisida secara berulang-ulang dan dosis yang semakin lama semakin tinggi telah memberikan dampak negatif, antara lain hama menjadi tahan terhadap insektisida, juga kemudian muncul hama baru, terbunuhnya musuh-musuh alami dan organisme non target (Untung, 1993). Selain itu, penyemprotan juga mengakibatkan tertinggalnya residu insektisida pada hasil tanaman, air dan tanah yang berdampak negatif pada kesehatan manusia dan hewan ternak (Sembel, 2012).

Penggunaan insektisida yang berlebihan telah mengancam kehidupan di dunia. Untuk itu sejak 20 tahun yang lalu, pemerintah telah menetapkan kebijakan untuk menerapkan konsep pengendalian hama terpadu (PHT) dalam sistem produksi pertanian, terutama tanaman pangan (Setyanto \& Subagyono, 2006). PHT adalah pendekatan ekologi yang bersifat multidisiplin untuk pengelolaan populasi hama dan memanfaatkan beranekaragam taktik pengendalian secara kompatibel dalam suatu kesatuaan koordinasi pengelolaan. Konsep PHT muncul di Indonesia dan berkembang sebagai respon terhadap kebijakan pengendalian hama secara konvensional yang menekankan penggunaan insektisida (Hasibuan, 2008), terutama pada pertanaman padi.

Inpari 10 merupakan salah satu varietas padi yang umum ditanam petani, khususnya pada musim gadu. Budidaya tanaman ini umumnya masih dilakukan secara konvensional. Belum tersedia informasi apakah PHT efektif untuk mengendalikan populasi hama pada pertanaman padi varietas Inpari 10. Penelitian ini bertujuan untuk membandingkan kepadatan populasi hama dan musuh alami pada pertanaman padi Varietas Inpari 10 yang dibudidayakan secara PHT dan Konvensional.

\section{BAHAN DAN METODE}

Penelitian ini bagian dari kegiatan SLPHT kelompok tani Sumber Rejeki yang dilakasanakan pada musim gadu bulan Juli-Oktober 2012. Pengamatan dilakukan di areal persawahan PHT dan konvensional di Desa Rawa Selapan, Kecamatan Candi Puro, Lampung Selatan dan identifikasi hama dan musuh alami dilakukan di Laboratorium Hama Tumbuhan Fakultas Pertanian Universitas Lampung.

Alat-alat yang digunakan pada penelitian ini ialah: lup, timbangan elektrik, panduan identifikasi serangga dan botol film. Bahan yang digunakan ialah alat tulis, bambu, benih padi, pupuk kandang (kotoran sapi) dan 
pupuk kimia PONSKA (mengandung N, P dan K), insektisida kimia, insektisida nabati dan alkohol.

Penelitian ini menggunakan Rancangan Acak Lengkap (RAL) dengan dua perlakuan dan enam ulangan. Perlakuan pertama adalah budidaya tanaman padi secara PHT dan perlakuan kedua adalah budidaya tanaman padi secara konvensional (non-PHT) (Tabel 1). Luas masing-masing unit petak perlakuan $50 \times 25$ $\mathrm{m}^{2}$. Penanaman dilakukan dengan pola jajar legowo 2:1 dengan jarak tanam 20x20x60 cm. Dari setiap petak perlakuan ditentukan secara sistematis enam titik/rumpun padi sampel (Gambar1).

Pengamatan dilakukan sebanyak 8 kali dan pengambilan data dilakukan secara visual. Pengamatan hasil panen dilakukan dengan menghitung bobot 10 malai setiap rumpun yang diamati. Analisis data dilakukan dengan menggunakan uji $\mathrm{F}$ pada taraf nyata $5 \%$. Langkah-langkah pelaksanaan penelitian ini sebagai berikut persiapan lahan, penyemaian dan penanaman, pemupukan dan pemeliharaan tanaman, serta pengamatan dan analisis data. Persiapan lahan meliputi kegiatan pengolahan tanah pada lahan PHT dan konvensional. Pengolahan tanah dilakukan dengan pembajakan, pembajakan dilakukan pada tanggal 08 Juni 2012 (Tabel 1). Lahan berukuran 50x50 $\mathrm{m}^{2}$ kemudian dibagi menjadi dua petak, yaitu $50 \times 25 \mathrm{~m}^{2}$ untukditanami padi secara PHT dan 50x25 ${ }^{2}$ untuk ditanami padi secara konvensional (non -PHT) (Gambar 1).

Benih padi yang digunakan yaitu Varietas Inpari 10. Sebelum ditebar benih padi direndam selama satu malam dengan menggunakan air hangat $\left(55^{\circ} \mathrm{C}\right)$ lalu dikeringanginkan selama dua hari. Kemudian benih disemai selama tiga minggu di petak persemaian. Setelah itu, padi dicabut dan dipindahtanam dengan jarak $20 \times 20 \times 60 \mathrm{~cm}$. Pada setiap petak perlakuan dipasang masing-masing enam bambu ajir sebagai penanda titik

Tabel 1. Kegiatan budidaya padi varietas Inpari 10 pada pertanaman lahan secara PHT dan secara non-PHT di lahan petani

\begin{tabular}{lrcl}
\hline \multicolumn{1}{c}{ Tanggal } & PHT & Non-PHT & Kegiatan \\
\hline 08 Juni 2012 & v & v & Pembajakan lahan \\
10 Juni 2012 & v & v & Penyemaian \\
02 Juli 2012 & v & v & Pencabutan bibit \\
03 Juli 2012 & v & v & Penanaman \\
09 Juli 2012 & v & v & Pemupukan 1 (Pupuk kandang +Pupuk Ponska) \\
24 Juli 2012 & v & v & Pemupukan 2 (Pupuk kandang +Pupuk Ponska) \\
18 Agustus 2012 & v & - & Penyemprotan insektisida nabati/(kunyit, jahe dan lengkuas) \\
03 Agustus 2012 & - & v & Penyemprotan insektisida kimia 1 (Poryza) \\
18 Agustus2012 & - & v & Penyemprotan insektisida kimia 2 (Poryza) \\
02 Oktober 2012 & v & v & Pemanenan \\
\hline
\end{tabular}

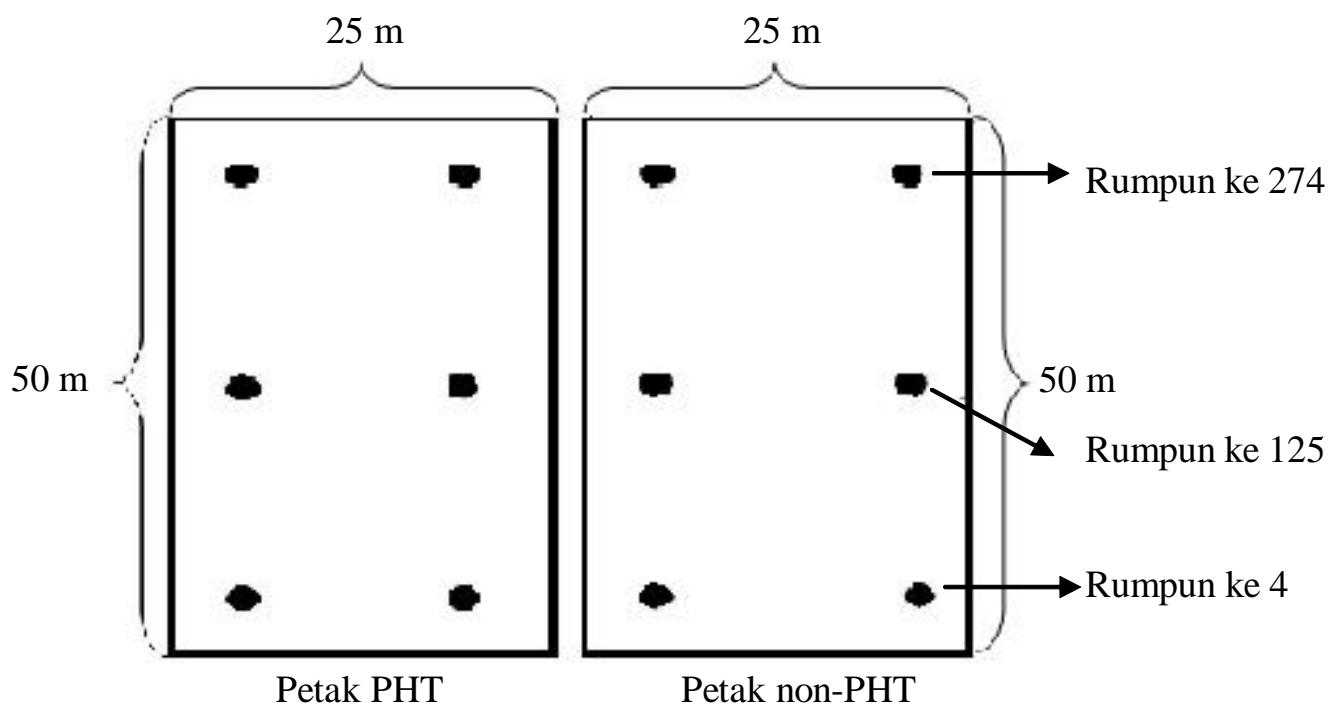

Gambar 1. Tata Letak Titik (Rumpun) Sampel. 
per rumpun yang akan diamati. Enam rumpun diambil secara sistematis, yaitu pada rumpun ke 4 , rumpun ke 125 (tengah) dan rumpun ke 247 (Gambar 1).

Pemupukan dilakukan dengan menggunakan pupuk urea ( $9 \mathrm{~kg} / 0,25 \mathrm{ha})$, Ponska $(9 \mathrm{~kg} / 0,25 \mathrm{ha})$, dan pupuk kandang (16 kg / 0,25 ha). Pemupukan ini dilakukan pada 6 hari setelah tanam (hst) dan 21 hst. Pemeliharaan tanaman meliputi penyulaman, penyiraman dan pengendalian hama dan penyakit. Penyulaman dilakukan ketika terdapat tanaman padi yang mati atau kurang baik pertumbuhannya. Penyulaman dilakukan maksimum 1 minggu setelah tanam, karena penelitian dilakukan pada musim kemarau maka diperlukan penyiraman. Kegiatan penyiraman dilakukan pada pagi atau sore hari dengan menggunakan mesin pompa air sumur bor dan pipa penyedot yang dialirkan ke lahan. Pengendalian hama dilakukan dengan melakukan penyemprotan insektisida kimia Poryza (bahan aktiv Dimehypo $400 \mathrm{~g} \mathrm{l}^{-1}$ ) dengan dosis $10 \mathrm{ml} /$ 0,125 ha pada perlakuan non- PHT dan penyemprotan insektisida nabati dengan menggunakan ekstrak kunyit, jahe dan lengkuas dengan dosis $480 \mathrm{ml} / 0,125$ ha pada perlakuan PHT. Penyiangan gulma dilakukan secara manual yaitu dengan cara mencabut gulma yang tumbuh dengan tangan atau dengan menggunakan cangkul dan arit. Pemanenan dilakukan dengan memisahkan 12 rumpun yang diamati.

Pengamatan dilakukan secara visual dan langsung, yaitu dengan menghitung jumlah hama dan musuh alami yang terlihat, baik pada petak PHT maupun pada petak konvensional (non-PHT). Pengamatan dilakukan 30 hari setelah pemindahtanam bibit padi ke lahan, sampai padi berumur 79 hst. Pengamatan dilakukan pada rumpun sampel tetap setiap minggu sekali, pada pagi hari. Hama dan musuh alami yang tidak diketahui familinya dikoleksi untuk diidentifikasi di laboratorium. Identifikasi hama dan musuh alami sampai tingkat famili menggunakan panduan Borror et al . (1992).

\section{HASIL DAN PEMBAHASAN}

Arthropoda yang didapatkan pada petak PHT tidak berbeda dengan arthropoda yang didapatkan pada petak non-PHT yaitu terdiri dari enam ordo dan terdapat 13 Famili. Arthropoda yang ditemukan meliputi kelompok hama, musuh alami dan tidak diketahui peranannya (Tabel 2). Perlakuan PHT dan non-PHT pada padi varietas Inpari 10 dari awal hingga akhir pengamatan tidak berpengaruh terhadap populasi hama (Tabel 3). Kepadatan populasi hama pada petak PHT dan non-PHT berada pada kisaran 1-17 ekor per rumpun.

Secara umum, kepadatan populasi musuh alami pada petak PHT dan non-PHT juga tidak berbeda nyata (Tabel 4). Pola ini mirip dengan pola hama (Tabel 3). Namun, ketika tanaman berumur 30 hst populasi musuh alami lebih tinggi di petak PHT daripada petak nonPHT (8 vs 1 ekor per rumpun). Pada waktu pengamatan seterusnya populasi musuh alami di petak PHT atau non-PHT tidak berbeda nyata, yaitu berkisar pada kepadatan 1-5 ekor per rumpun.

Hasil penelitian menunjukan bahwa kepadatan populasi hama pada petak PHT tidak lebih tinggi dibandingkan dengan yang dibudidayakan secara nonPHT (Konvensional). Kepadatan populasi musuh alami secara umum juga tidak menunjukan perbedaan antara petak PHT dengan non- PHT kecuali pada 30 hst. Penggunaan bahan kimia dalam pengolahan lahan pertanian dapat menyebabkan terpaparnya bahan tersebut di lingkungan, maka kemungkinan ada spesies

Tabel 2. Arthropoda yang ditemukan pada petak percobaan tanaman padi PHT dan non-PHT.

\begin{tabular}{clc}
\hline Ordo & \multicolumn{1}{c}{ Famili } & Peran dalam Agroekosistem \\
\hline Coleoptera & Coccinellidae & Musuh alami \\
& Staphylinidae & \\
Orthoptera & Acrididae & Hama \\
Hemiptera & Delphacidae & Hama \\
& Pentatomidae & \\
& Alydidae & \multirow{2}{*}{ Musuh alami } \\
Hymenoptera & Vespidae & Tidak diketahui \\
Diptera & Formicidae & \\
& Tipulidae & Musuh alami \\
Araneae & Milichidae & \\
& Araneidae & \\
& Tetragnathidae & Oxyopidae
\end{tabular}


Tabel 3. Populasi hama pada perlakuan PHT dan non PHT pada pertanaman padi varietas Inpari 10

\begin{tabular}{cccc}
\hline Pengamatan & $\begin{array}{c}\text { non PHT } \\
\text { (ekor per rumpun) }\end{array}$ & $\begin{array}{c}\text { PHT } \\
\text { (ekor per rumpun) }\end{array}$ & F-hitung \\
\hline $30 \mathrm{hst}$ & 4,2 & 4,7 & $0,05 \mathrm{tn}$ \\
$37 \mathrm{hst}$ & 2,5 & 6,2 & $4,90 \mathrm{tn}$ \\
$44 \mathrm{hst}$ & 1,8 & 2,7 & $0,31 \mathrm{tn}$ \\
$51 \mathrm{hst}$ & 3,0 & 3,3 & $0,03 \mathrm{tn}$ \\
$58 \mathrm{hst}$ & 1,7 & 3,2 & $0,96 \mathrm{tn}$ \\
$65 \mathrm{hst}$ & 8,5 & 7,5 & $0,34 \mathrm{tn}$ \\
$72 \mathrm{hst}$ & 10,5 & 17,8 & $1,10 \mathrm{tn}$ \\
$79 \mathrm{hst}$ & 2,8 & 3,7 & $0,20 \mathrm{tn}$ \\
\hline Rata-rata & 4,4 & 6,1 & $1,83 \mathrm{tn}$ \\
\hline
\end{tabular}

Keterangan : $\mathrm{tn}=$ tidak berbeda nyata berdasarkan uji $\mathrm{F}$ pada $\alpha_{0,05}$.

Tabel 4. Populasi musuh alami pada perlakuan PHT dan non PHT pada pertanaman padi varietas Inpari 10

\begin{tabular}{cccc}
\hline Pengamatan & $\begin{array}{c}\text { non PHT } \\
\text { (ekor per rumpun) }\end{array}$ & $\begin{array}{c}\text { PHT } \\
\text { (ekor per rumpun) }\end{array}$ & F-hitung \\
\hline $30 \mathrm{hst}$ & 1,3 & 8,0 & $5,85 *$ \\
$37 \mathrm{hst}$ & 4,2 & 5,3 & $0,19 \mathrm{tn}$ \\
$44 \mathrm{hst}$ & 2,8 & 4,7 & $1,17 \mathrm{tn}$ \\
$51 \mathrm{hst}$ & 2,8 & 3,7 & $0,19 \mathrm{tn}$ \\
$58 \mathrm{hst}$ & 1,7 & 4,7 & $2,74 \mathrm{tn}$ \\
$65 \mathrm{hst}$ & 1,7 & 2,2 & $0,34 \mathrm{tn}$ \\
$72 \mathrm{hst}$ & 2,2 & 4,0 & $1,84 \mathrm{tn}$ \\
$79 \mathrm{hst}$ & 2,5 & 5,3 & $1,87 \mathrm{tn}$ \\
\hline Rata-rata & 2,6 & 4,7 & $4,50 \mathrm{tn}$ \\
\hline
\end{tabular}

Keterangan $:$ tn $=$ tidak berbeda nyata dan $*=$ berbeda nyata, berdasarkan uji $\mathrm{F}$ pada $\alpha_{0,05}$.

Arthropoda tertentu yang mati atau meninggalkan tempat tersebut. Hal ini dapat berakibat pada kelimpahan dan keanekaragaman Arthropoda di sawah yang diaplikasi insektisida menjadi rendah (Herlinda $d k k ., 2008)$. Musuh alami lebih efektif dalam mengonsumsi serangga hama pada pertanaman yang dikelola secara PHT yang tidak diaplikasi insektisida kimia, sehingga pada budidaya pertanaman secara PHT musuh alami dapat berperan dalam mengurangi serangan hama di pertanaman padi (Purnomo, 2010). Hama yang terus menerus mendapat tekanan insektisida dapat membentuk strain yang lebih tahan terhadap insektisida tertentu yang biasanya digunakan oleh para petani (Untung, 1993).

Hasil penelitian menunjukan bahwa Varietas Inpari 10 yang dibudidayakan secara PHT lebih baik jika dibandingkan dengan varietas padi lainnya seperti Varietas Ciherang. Pada penelitian Hutagalung (2013), populasi hama pada petak PHT lebih tinggi dan hasil panen pada petak PHT lebih rendah dibandingkan dengan non-PHT. Modal yang dikeluarkan pada pertanaman padi Varietas Inpari 10 secara PHT lebih rendah dibandingkan non-PHT, namun hasil panen tidak berbeda. Dengan demikian, penggunaan Varietas Inpari 10 yang dibudidayakan secara PHT lebih baik digunakan oleh para petani dibandingkan dengan budidaya secara non-PHT, karena selain tidak berdampak negatif bagi lingkungan, budidaya PHT juga dapat menekan biaya pengeluaran petani seperti penggunaan insektisida, sehingga hasil yang diperoleh tidak menurun.

\section{KESIMPULAN}

Kesimpulan dari penelitian ini adalah populasi hama pada pertanaman secara PHT tidak lebih tinggi dari Konvensional. Populasi musuh alami pada pertanaman secara PHT pada umumnya juga tidak lebih tinggi dari Konvensional (non-PHT) kecuali pada pengamatan $30 \mathrm{hst}$ populasi musuh alami pada pertnaman secara PHT lebih tinggi dibandingkan dengan konvensional (non-PHT). 


\section{DAFTAR PUSTAKA}

Borror, D. J., C. A. Tripplehorn, dan N. F. Johnson. 1992. Pengenalan Jenis Serangga. Edisi Keenam. Penerjemah. S. Partosoedjono. Gajah Mada University Press. Yogyakarta.

Hasibuan, M. 2008. Kajian penerapan PHT pada petani padi di Kabupaten Tapanuli Selatan. Universitas Sumatra Utara. Medan.

Herlinda, S., Waluyo, Estuningsih, dan I. Chandra. 2008. Perbandingan Keanekaragaman Spesies dan Kelimpahan Arthropoda Predator Penghuni Tanah di Sawah Lebak yang Diaplikasi dan Tanpa Aplikasi Insektisida. J. Entomol. Indon. 5 (2): 99-100.

Hutagalung, S. 2013. Populasi Hama dan Musuh Alami pada Pertanaman Padi Varietas Ciherang Yang Dikelola Secara PHT Versus Konvensional (NonPHT). Skripsi. Fakultas Pertanian, Universitas Lampung.
Purnomo, H. 2010. Pengantar Pengendalian Hayati. Andi Ofset. Yogyakarta.

Sembel, D. T. 2012. Dasar-Dasar Perlindungan Tanaman. Fakultas Pertanian Universitas Sam Ratulangi. Manado.

Setyanto, A.P. dan K. Subagyono. 2006. Isu dan Pengelolaan Lingkungan dalam Revitalisasi Pertanian. Balai Besar Penelitian dan Pengembangan Sumber Daya Lahan Pertanian. Indonesia

Untung, K. 1993. Pengantar Pengelolaan Hama Terpadu. Gadjah Mada University Press. Yogyakarta. 